\title{
Potential Use of Silver Nanoparticles on Pathogenic Bacteria, their Toxicity and Possible Mechanisms of Action
}

\author{
Nelson Durán, ${ }^{*, a}$ Priscyla D. Marcato, ${ }^{a}$ Roseli De Conti, ${ }^{a}$ Oswaldo L. Alves, ${ }^{a}$ \\ Fabio T. M. Costa ${ }^{b}$ and Marcelo Brocchi ${ }^{b}$ \\ ${ }^{a}$ Instituto de Química and ${ }^{b}$ Instituto de Biologia, Universidade Estadual de Campinas, \\ 13083-970 Campinas-SP, Brazil
}

\begin{abstract}
As propriedades da prata são conhecidas há muitos anos. Recentemente, as nanopartículas de prata têm chamado a atenção por sua atividade antimicrobiana que oferece a possibilidade de uso com propósitos médicos e de higiene. Estas nanopartículas de prata em diferentes formulações, com diferentes formas e tamanhos, exibem atividades antimicrobianas diferentes. Entretanto, os mecanismos da atividade antimicrobiana de íons e de nanopartículas, assim como sua toxicidade em tecidos humanos não estão totalmente esclarecidos. Esta revisão avalia o uso potencial de nanopartículas de prata no controle de patogênicos com ênfase sobre sua ação contra bactérias patogênicas, sua toxicidade e possíveis mecanismos de ação.
\end{abstract}

The antimicrobial properties of silver have been known for thousands of years. Recently, silver nanoparticles have gained attention because of their antimicrobial activity which offers the possibility of their use for medical and hygiene purposes. Indeed, silver nanoparticles in different formulations and with different shapes and sizes exhibit variable antimicrobial activity. However, the mechanisms of antimicrobial activity of silver ions and silver nanoparticles, and their toxicity to human tissues are not fully characterized. This review evaluates the potential use of silver nanoparticles to control pathogens with emphasis on their action against pathogenic bacteria, their toxicity and possible mechanisms of action.

Keywords: silver nanoparticles, silver ions, antimicrobial activity, toxicity

\section{Introduction}

There is a growing concern about the emergence and re-emergence of drug-resistant pathogens such as multiresistant bacterial strains, fungi and parasites. ${ }^{1}$ Therefore, the development of new antimicrobial compounds or the modification of those available in order to improve antimicrobial activity for therapy, antisepsis or disinfection is a high priority area of research. In this endeavor, nanotechnology provides a means to modify key features of different materials, including metal nanoparticles. ${ }^{2,3}$ The inhibitory and bactericidal activities of silver ions have long been known. ${ }^{4-7}$ Some forms of silver have been demonstrated to be effective against burn infections, severe chronic osteomyelitis, urinary tract infections and central venous catheter infections. ${ }^{8}$ Based on these results, many silver-based antimicrobial materials have become available and several others are under development in research laboratories. ${ }^{2,9}$ In addition to

*e-mail: duran@iqm.unicamp.br antimicrobial activity, the mechanisms of action and toxicity are also of paramount importance and several studies are under way to better elucidate these aspects.

Metallic nanoparticles can be obtained by physical, chemical or biological methods. However, biological synthesis is reliable and eco-friendly, and has received particular attention. In fact, a number of different species of bacteria and fungi are able to reduce metal ions producing metallic nanoparticles with antimicrobial properties. ${ }^{10-16}$ Recently, efficient antibacterial activity was observed against multidrug resistant and highly pathogenic bacteria, including multidrug resistant Staphylococcus aureus, Salmonella typhi, Staphylococcus epidermidis and Escherichia coli by silver nanoparticles produced by the fungus $F$. acuminatum. ${ }^{17}$ Additionally, plant extracts can also be used to obtain metallic nanoparticles. ${ }^{18,19}$

This review discusses the current worldwide research on the use of silver nanoparticles to fight pathogenic microorganisms. It focuses on anti-microbial activities, silver nanoparticle/antibiotic association and toxicity. 


\section{Silver Nanoparticles Biological Activities}

\subsection{Antibacterial and bactericidal activities}

The inhibitory effect of silver is probably the sum of distinct mechanisms of action. A number of studies suggest that silver ions react with $\mathrm{SH}$ groups of proteins $\mathrm{s}^{20,21}$ and play an essential role in bacterial inactivation.? Micromolar levels of silver ions have been reported to uncouple respiratory electron transport from oxidative phosphorylation, which inhibits respiratory chain enzymes or interferes with membrane permeability to protons and phosphate. ${ }^{21}$ Studies conducted by Feng et al. ${ }^{21}$ and by Jung et al. ${ }^{22}$ have shown the activity of silver ions on Escherichia coli (Gram-negative) and Staphylococcus aureus (Grampositive), respectively. Feng et al. ${ }^{21}$ treated these bacteria with $\mathrm{AgNO}_{3}$ and studied the effects on cell morphology using combined electron microscopy (TEM and SEM) and X-ray microanalyses. E. coli and S. aureus underwent similar morphological changes after silver ion treatment characterized by a cytoplasm membrane detachment from cell walls and the appearance of an electron-light region in the center of the cells, which contained condensed deoxyribonucleic acid (DNA) molecules probably formed to protect DNA from injuries mediated by the silver ions. Small electron-dense granules either surrounding the cell wall or deposited inside the cells were also present. ${ }^{21}$ Recently, Jung et $a l .{ }^{22}$ reported results corroborating the morphological changes described by Feng et al. ${ }^{21}$ and also suggested that in the presence of silver ions, bacterial cells reach an active but non-culturable state and eventually die. Jung et al. $^{22}$ also suggested that the thickness of the peptidoglycan layer of gram-positive bacteria may prevent to some extent, the action of the silver ions, since they found a higher inhibitory activity of silver ion solution against $E$. coli than against $S$. aureus which also corroborates the conclusion of Feng et al. ${ }^{21}$

The presence of silver ions and sulfur in the electrondense granules observed after silver ions treatment in the cytoplasm of bacterial cells suggests an interaction with nucleic acids that probably results in impairment of DNA replication. ${ }^{21}$

Silver ions and silver nanoparticles also have inhibitory and lethal effects on bacterial species such as E. coli, ${ }^{9,23-25}$ $S$. aureus $^{9}$ and even yeast. ${ }^{9}$ In the last paper, the authors have prepared silver nanoparticles by mixing silver nitrate with sodium borohydride to obtain particles that were highly monodispersed with an average diameter of $13.5 \pm 2.6 \mathrm{~nm}$. They have observed that yeast and $E$. coli were inhibited at low concentrations of nanoparticles, 6.6 and $3.3 \mathrm{nmol} \mathrm{L}^{-1}$, respectively, whereas the growth-inhibitory activity on $S$. aureus was mild, with the minimal inhibitory concentration (MIC) estimated to be higher than $33 \mathrm{nmol} \mathrm{L}{ }^{-1}$. This study also suggested that the generation of free-radicals is involved in some way with the antimicrobial activity of silver nanoparticles. In fact, oxidative stress was observed in cells after silver nanoparticles interaction. ${ }^{26}$ However, results described by Lok et al. ${ }^{27}$ differ in some way with those obtained by Kim et al. ${ }^{9}$ regarding the involvement of freeradicals in the antimicrobial activity of silver nanoparticles. Further studies are therefore required in order to clarify the exact role of free-radicals.

Raffin et al. ${ }^{28}$ observed that silver nanoparticles with mean sizes of $16 \mathrm{~nm}$ were completly cytotoxic for $E$. coli at a low concentration $\left(60 \mu \mathrm{g} \mathrm{mL}^{-1}\right)$. The assay was carried out in liquid and solid growth media and was verified by transmission electron microscopy (TEM). Silver nanoparticles were observed to adhere to the cell wall and were also found inside the bacteria. Gade et al. ${ }^{29}$ produced silver nanoparticles by extracellular biosynthesis using Aspergillus niger isolated from soil. Particles with $20 \mathrm{~nm}$ were cytotoxic to E. coli and TEM analysis indicated the complete disruption of the bacterial membrane after few minutes in contact with silver nanoparticles. This result shows the high efficiency of silver nanoparticles due to the large surface area available for interactions. ${ }^{28}$

Morones et al. ${ }^{7}$ tested the activity of silver nanoparticles in E. coli, Vibrio cholerae, Pseudomoma aeruginosa and Salmonella enterica Typhi (all species of Gram-negative bacteria). Release of silver nanoparticles in powder form from a carbon matrix showed a large size distribution. Only individual particles were observed to be attached to the surface of the bacterium membrane. The mean size of these silver nanoparticles interacting with bacteria was $5 \pm 2 \mathrm{~nm}$. Particles were found in the bacteria membrane and inside the cells. The particles sizes in the membrane and inside the cells were similar, suggesting that the particles that interact with the membrane are able to invade the bacteria. Furthermore, particles penetration was size dependent. Particles with sizes between 1-10 nm interact preferentially with bacteria. This particle penetration ability was also verified by Sondi and Salopek-Sondi. ${ }^{23}$ In this study was observed an accumulation of silver nanoparticles on the E. coli cell membranes, while some penetrated into the cells. This difference in silver nanoparticle distribution in the cell can be due to particle size.

The comparison of the antimicrobial effect of silver ions and silver nanoparticles is an interesting field of research and some studies were performed in this direction. Morones et al. ${ }^{7}$ showed that the overall effect of the silver nanoparticles was different from the effect of only silver ions. When nanoparticles were used in this study, no 
evidence was found for the formation of a low density region as reported previously by Feng et al. ${ }^{21}$ for silver ions. Instead, a large number of small silver nanoparticles were observed inside the bacteria. The results of Morones et al. ${ }^{7}$ also indicate that silver ions present in the nanoparticle solution contributed but it is not the sole mechanism of antimicrobial activity induced by nanosilver.

Recently, proteomic analysis revealed that even a short exposure of silver nanoparticles to E. coli cells resulted in alterations in the expression of a panel of envelope and heat shock proteins. ${ }^{30}$ Therefore, these particles can penetrate and can disrupt the membranes of bacteria. A massive loss of intracellular potassium was induced by silver nanoparticles. Furthermore, the silver nanoparticles decreased the ATP levels. Both effects may culminate in the loss of cell viability. Similar results were observed with silver ions. ${ }^{30}$ However, the major difference between silver nanoparticles and silverions is on their effectiveness against bacteria, which are at nanomolar concentrations in the case of nanoparticles and in the micromolar ranges in the case of silver ions. The possible molecular targets for these silver species could be protein thiol groups (key respiratory enzymes). The phospholipid portion of the bacterial membrane may also be the site of action for the silver species. ${ }^{30}$

A pivotal matter of the employment of silver species as antimicrobial agents is the selection of resistant microorganisms. Although clinical incidence of silver resistance remains scarce, this resistance can increase due to the great number of products with silver that liberate silver ions into the environment. ${ }^{31}$ Silver $^{32}$ described the resistance mechanisms against silver ions exhibited by bacteria in detail at the molecular level. Resistant microorganisms are present in environments where silver salts (e.g., silver nitrate, silver sulfadiazine) are used as antiseptics, such as in burn wards of hospitals. Chromosomic or plasmidial genes responsible for silver resistance have been studied by molecular techniques. For instance, silver ion resistance in Salmonella enterica is mediated by nine genes organized in three transcription units present in plasmid pMGH100. A sensor/responder, two-component transcriptional regulatory system governs synthesis of a periplasmic silver ion-binding protein together with two efflux pumps, a P-type ATPase plus a three-protein chemiosmotic silver ion/ $\mathrm{H}^{+}$exchange system. The centrally located six genes of this operon were found and were functional in the genome of other bacteria including different strains of E. coli. ${ }^{32,33}$

A recent synthesis of silver nanoparticles using a reduction of aqueous silver ions with the culture supernatants of Staphylococcus aureus was reported. The silver nanoparticles were evaluated for their antimicrobial activities against different pathogenic organisms. The highest sensitive antimicrobial activity was observed against Methicillin resistant Staphylococcus aureus (MRSA) followed by Methicillin resistant Staphylococcus epidermidis (MRSE) and Streptococcus pyogenes; while with Salmonella typhi and Klebsiella pneumoniae moderate antimicrobial activity was observed. ${ }^{34}$

\subsection{Antimicrobial activities and silver nanoparticle size and shape}

Recent results suggest that silver nanoparticles undergo a shape-dependent interaction with the bacterial cells. Pal et al. ${ }^{35}$ demonstrated that truncated triangular silver nanoplates displayed the strongest biocidal action against E. coli, when compared with spherical and rod-shaped nanoparticles and also with silver ions. Similar conclusions were reached by Sharma et al. ${ }^{36}$

The size of the particle plays a central role in antimicrobial activity. In a recent study, colloidal silver particles, with variable sizes $(44,50,35$, and $25 \mathrm{~nm})$, synthesized by the reduction of $\left[\mathrm{Ag}\left(\mathrm{NH}_{3}\right)_{2}\right]^{+}$complexes with carbohydrates were tested for antimicrobial activity. The antibacterial activity was particle size dependent. Small particles exhibited higher antimicrobial activity than big particles. ${ }^{37}$ This result can be due to high particle penetration when these particles have smaller sizes. ${ }^{7}$ In another study, the antibacterial activity towards E. coli of gel hybrids containing silver nanoparticles of different sizes, i.e., $2.67 \mathrm{~nm}, 6.63 \mathrm{~nm}$, and $21.11 \mathrm{~nm}$, were examined and compared with silver nanoparticles ( $c a .220 \mathrm{~nm}$ ) without any stabilization. The results showed that the silver nanoparticles of $2.67 \mathrm{~nm}$ protected by hydrogel polymer chains present an excellent antibacterial activity compared to the larger sized silver nanoparticles in the hybrid networks. ${ }^{25}$ These authors concluded that the lower sized nanoparticles in the hydrogel probably diffused more easily than the larger ones, which explains the higher toxicity on the E. coli strain used in this study.

The influence of size on antimicrobial activity was also investigated by Baker et al. ${ }^{6}$ In this study, the antibacterial properties were related to the total surface area of the nanoparticles. Smaller particles with larger surface to volume ratios have greater antibacterial activity. Similar results were published by Choi and $\mathrm{Hu}^{38}$

The synthesis of silver nanocrystals encapsulated in mesoporous silica nanoparticles with a yolk/shell structure has been described, and demonstrate their antimicrobial effect. A complete inhibition of bacterial growth was reached with $100 \mu \mathrm{g} \mathrm{mL}^{-1}$ of the particles. These silvercontaining nanoparticles may be used as a promising 
alternative to the current technologies involving the use of silver nanoparticles and silver-doped materials as antimicrobial coatings and colloidal suspensions. ${ }^{39}$

\subsection{Silver nanoparticles and antibiotics}

The association of metal nanoparticles and antibiotics is a very promising area of research. Nanosilver particles are interesting when compared with silver ions due to their larger size, which, in turn, improves the capacity to react with several molecules. In fact, larger chelated compounds can produce different antimicrobial effects and even a synergistic antibacterial effect has been observed. ${ }^{40}$ In this study, the bactericidal action of silver nanoparticles and amoxicillin was investigated using E. coli as a model and silver nanoparticles of $20 \mathrm{~nm}$ in size (prepared by reducing an aqueous solution of $\mathrm{AgNO}_{3}$ with a freshly prepared aqueous ascorbic acid solution and ammonia). Microbiological tests confirm that combining amoxicillin with silver nanoparticles results in a synergistic antibacterial effect on $E$. coli cells. In this study, the amount of $5 \mu \mathrm{g} \mathrm{mL}^{-1}$ of silver nanoparticles caused no obvious effect on bacterial growth and $0.15 \mathrm{mg} \mathrm{mL}^{-1}$ of amoxicillin caused a minor delay in the growth, but the combination of these drugs in these same concentrations caused a significant reduction of growth, which can probably be explained by the synergistic action of these two antimicrobial compounds.

To explain the mechanism of this synergistic antibacterial effect, Li et al..$^{40}$ proposes that silver nanoparticles and amoxicillin exhibit different mechanisms of action
(Figure 1). Moreover, the synergism is probably caused by a binding reaction between amoxicillin and silver nanoparticles, since amoxicillin molecules exhibit groups such as hydroxyl and amido groups that can react easily with silver nanoparticles. The authors did not mention the sulfur bridge in the molecule that probably is the most important binding site with the silver nanoparticles. Therefore, in addition to its antimicrobial activity, the silver nanoparticles probably operate as an antibiotic carrier.

The availability of biosynthetically produced silver nanoparticles ${ }^{10,41-44}$ opens the possibility to investigate the association of these biological particles with antibiotics. A recent study was carried out with clindamycin and silver nanoparticles produced chemically or biosynthetically (Figure 2). ${ }^{45}$ The silver nanoparticles were chemically associated with clindamycin and purified before being used as an antibacterial compound (Figure 3). Preliminary results with these two formulations conducted in the presence of several bacteria, such as methicillin-resistant $S$. aureus strains (MRSA) and Staphylococcus epidemidis showed a significant bactericidal activity of both formulations with slightly lower MIC values observed with the biosynthetic nanoparticles. However, this activity was dependent upon the bacterial strain analyzed and also on the size of the nanoparticles. In addition, the biosynthetically produced nanoparticles were more stable than the chemical ones. ${ }^{45}$ Beside this, a study on the effect of silver nanoparticles associated with clindamycin on leishmaniasis was published. ${ }^{46}$

Recently, the combination of the silver nanoparticles with different antibiotics was investigated for activity
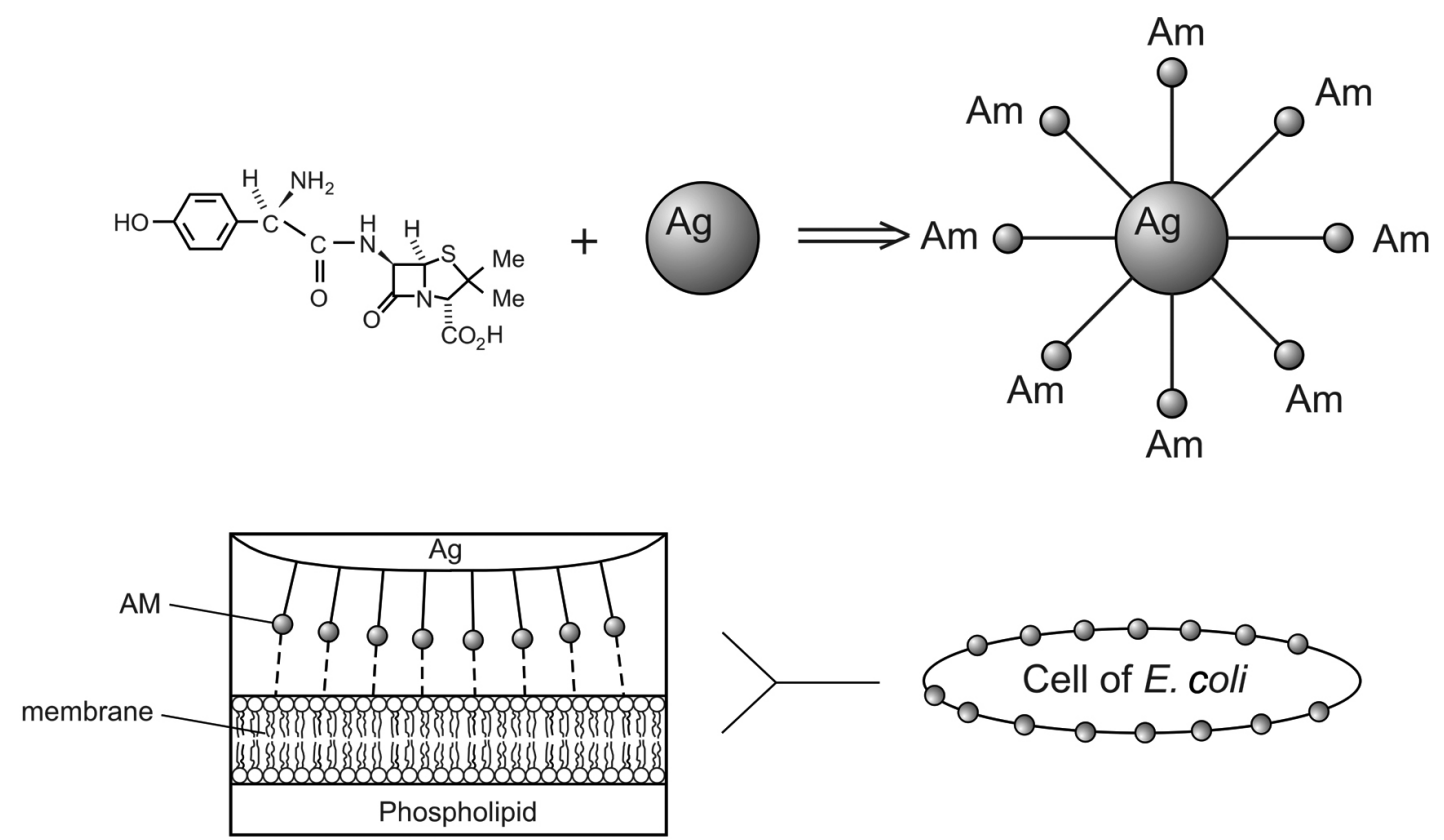

Figure 1. Structure of amoxicillin and the bonding route for silver nanoparticles chelated with amoxicillin and a diagram of the combination of chelate reacted with cells (Adapted from reference 40). 


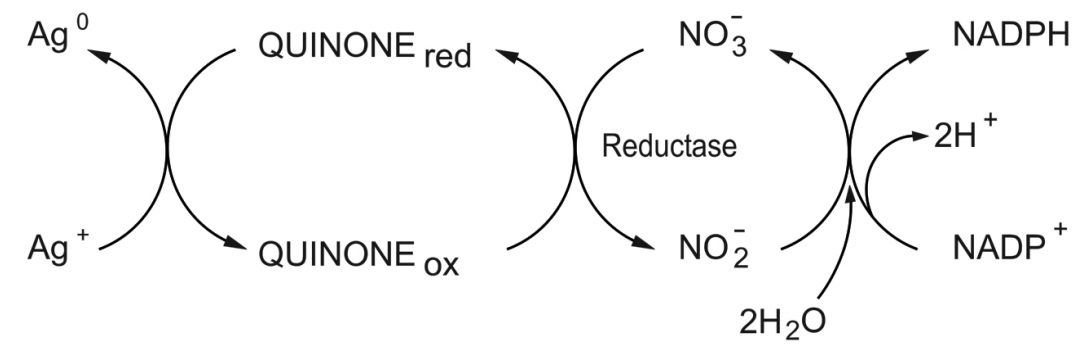

Figure 2. Diagram of the silver nanoparticles formation by fungi (Adapted from reference 10).

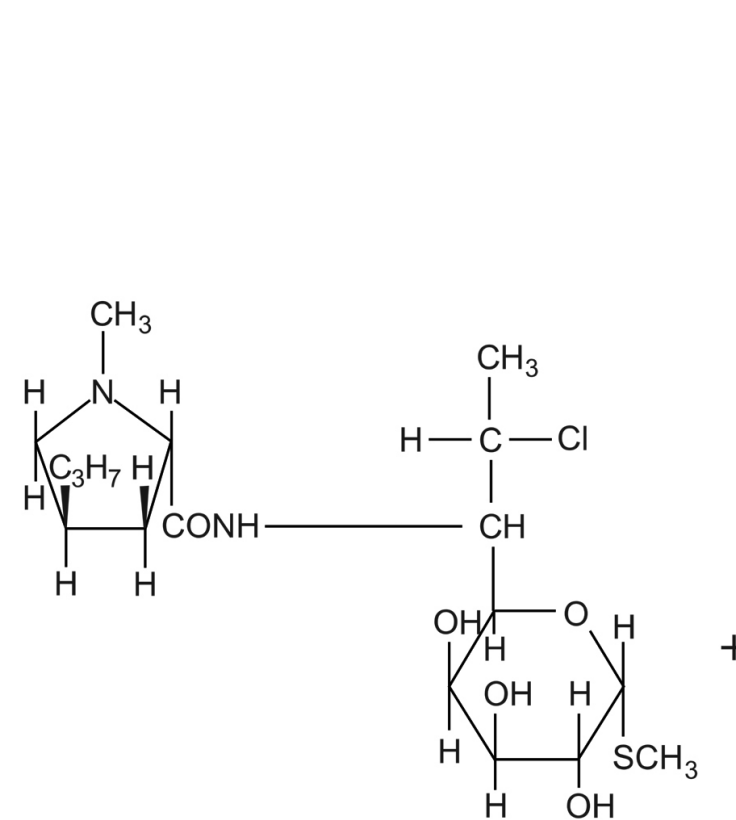<smiles>CC(Cl)C(C)NC(=O)C1CCCC1C</smiles>

$\mathrm{H} \mathrm{H}$

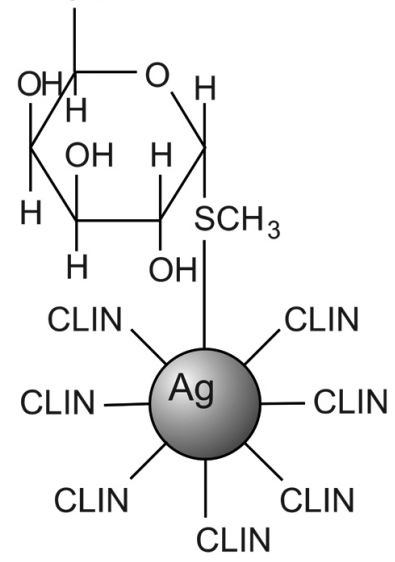

\section{CLIN}

\section{Chemical Synthesis or Fungal Synthesis}

Figure 3. Structures and diagram of the complex between clindamycin and silver nanoparticles produced by chemical and biologically methods.

against $S$. aureus and E. coli. The antibacterial activities of penicillin G, amoxicillin, erythromycin, clindamycin, and vancomycin increased in the presence of silver nanoparticles against both tested bacterial strains. ${ }^{47}$

Also, nineteen antibiotics were recently studied for antimicrobial activity in combination with the SilverWater Dispersion ${ }^{\mathrm{TM}}$ solution (15 nm diameter silver nanoparticles clusters containing silver ions produced by an electro-colloidal silver process). The minimal inhibitory concentrations were determined for the antibiotics and in combination with the Silver-Water Dispersion ${ }^{\mathrm{TM}}$ solution (De Souza et al.). ${ }^{48}$ This study evaluated the susceptibility of Gram-positive and Gram-negative bacteria strains such as multiple-drug resistant (MDR) E. coli, S. aureus, Salmonella enterica Typhi, Shigella flexineri and Bacillus subtilis. Based on the results for amoxicillin and clindamycin, as examples, experiments measuring the effect of association between Silver-Water Dispersion with amoxicillin showed an additive effect on S. aureus $6538 \mathrm{P}$ strain, S. enterica Typhi, S. flexneri and B. subtilis but an antagonistic effect was observed with a meticillin-resistant S. aureus strain (MRSA). On the other hand, the results with clindamycin showed only additive effect on MRSA, S. aureus 6538 P, S. flexneri and B.subtilis. ${ }^{48}$

Several antibiotics such as ampicillin, gentamycin, kanamycin, streptomycin and vancomycin were tested with silver nanoparticles produced from Phoma glomerata. The antibacterial activities of these antibiotics were increased in combination with silver nanoparticles against the Gramnegative micro-organisms, i.e., E. coli and Pseudomonas aeruginosa, as compared with Staphylococcus aureus as a better synergistic activity was observed with $E$. coli and Pseudomonas aeruginosa than with Staphylococcus aureus. ${ }^{49}$

These syntheses of norvancomycin-capped silver nanoparticles and their in vitro antibacterial activities 
against $E$. coli were recently studied. Mercaptoacetic acidstabilized spherical silver nanoparticles with a diameter of $16 \pm 4 \mathrm{~nm}$ were prepared. The TEM images of single bacteria treated with these nanoparticles showed aggregation in the cell wall of E. coli. A possible antibacterial mechanism was proposed where silver nanoparticles could destroy the stability of the outer membrane of $E$. coli, which makes the silver nanoparticles easier to bind to the lower part of the peptidoglycan structure..$^{50}$

A study on silver nanoparticles as an active carrier for chloramphenicol (CHL) in polyvinylpyrrolidone (PVP) has been published. PVP plays a dual role in such studies wherein it acts as a stabilizing agent as well as a link for binding the CHL to the silver nanoparticles. The percentage loading of the drug onto the silver nanoparticles was found to be $81 \%$. The drug-loaded silver nanoparticles showed substantially enhanced activity against clinically isolated S. typhi, thus showing considerable promise for further development. ${ }^{51}$

These data are indicative that the association of silver nanoparticles with antibiotics is a very promising strategy to control antimicrobial resistant bacteria. Questions such as differences between the pre-formulated nanoparticles bound to the antibiotics versus the simultaneous addition of the silver nanoparticles and the antibiotics as well as the comparison of silver nanoparticles produced chemically or biosynthetically, merit more profound investigation.

\subsection{Toxicity}

The results described above indicate the beneficial impact of metallic nanoparticles on human health. However, some studies indicate that certain nanoparticles may cause adverse effects due to their small size and properties. ${ }^{45,52,53}$ The small size makes them highly mobile both in the human body and the environment. ${ }^{54}$ Nanoparticles can gain access to the body by inhalation, ${ }^{55}$ by oral ingestion (Jani et al. ${ }^{56} 1990$ ) and probably by contact with the skin. ${ }^{57}$ After uptake, nanoparticles can disseminate to different body tissues. ${ }^{58-61}$ However, few toxicology studies are presently available.

Burd et al. ${ }^{62}$ studied the cytotoxicity of five commercially available dressings on the market containing silver ion or metallic nanocrystalline silver: Acticoat ${ }^{\mathrm{TM}}$, Aquacel ${ }^{\circledR} \mathrm{Ag}$, Contreet ${ }^{\circledast}$ Foam, PolyMem ${ }^{\circledast}$ Silver and Urgotul ${ }^{\circledR}$ SSD. All dressings were pretreated with different solutions and the cytotoxicity assay was performed. The study confirmed that the cytotoxicity was dependent on the dressing and on the concentration of silver in the pretreatment solution. The cytotoxicity in various cultures such as a monolayer cell culture, a tissue explant culture model and a mouse expurgated wound model was also studied. The results showed that c, Aquacel ${ }^{\circledR} \mathrm{Ag}$ and Contreet ${ }^{\circledR}$ Foam presented the most significant cytotoxic effects in keratinocyte and fibroblast cultures.

Recently, Acticoat ${ }^{\mathrm{TM}}$ was used in post-cardiac surgery mediastinitis using a recently introduced silver-releasing dressing claiming prompt antibacterial activity. In all four patients negative cultures were obtained within a maximum of $72 \mathrm{~h}$ and patients were discharged within a maximum of 20 days. ${ }^{63}$

Hussain et al. ${ }^{64}$ evaluated the acute toxicity of different metallic nanoparticles in vitro using a rat liver derived cell line (BRL 3A) (ATCC, CRL-1442 immortalized rat liver cells). Different sizes of silver nanoparticles (15 or $100 \mathrm{~nm}$ ) were evaluated for their potential toxicity. Exposure to silver nanoparticles for $24 \mathrm{~h}$ resulted in dose-dependent cytotoxicity. Mitochondrial function decreased significantly in cells exposed to the nanoparticles and cells treated with higher doses of particles exhibited cellular shrinkage and irregular shape ${ }^{64}$ Cytotoxicity is also dependent on the size of the particle. Similar results were recently reported for rat neuronal cells exposed to metal nanoparticles. The cells presented a decrease in size, an irregular shape and a significant dose-dependent impairment of the mitochondrial function. ${ }^{26}$

The toxicity of different types of nanoparticles on the C18-4 cells of a mouse cell line with spermatogonial stem cell characteristics was evaluated. ${ }^{54}$ Initially, silver, molybdenum, and aluminum nanoparticles with sizes of 15,30 and $30 \mathrm{~nm}$, respectively, were prepared using a commercial pulsed-plasma reactor, which forms the particles in a gas phase process. Silver nanoparticles were the most toxic among the nanoparticle types tested. Phase contrast microscopy showed changes induced by silver nanoparticles at concentrations starting at $10 \mu \mathrm{g} \mathrm{mL}^{-1}$. Cell apoptosis was also noticed. In general, the inhibition of mitochondrial activity increased with the increase of the silver nanoparticle concentration. However, for this same cell line, silver carbonate showed no significant cytotoxic effect on mitochondrial function and cell viability up to concentrations of $100 \mu \mathrm{g} \mathrm{mL}^{-1}$ (EC50 value of $408 \mu \mathrm{g} \mathrm{mL}^{-1}$ ). The results obtained with silver carbonate, which was used as a control, were in sharp contrast with the cytotoxicity observed with the silver nanoparticles, indicating that silver in a nanoparticulated form could be toxic to tissues. ${ }^{54}$

The cytotoxicity of a wide range of manufactured nanoparticulate materials, which were characterized by transmission electron microscopy (TEM) and ancillary analytical techniques to observe the particle crystallinity, was studied using an established cell line of murine alveolar 
macrophages.$^{65}$ In this study, chrysotile asbestos was used as a positive control. The result indicated an increased toxicity for silver versus asbestos. Asbestos has an extreme fiber geometry (aspect ratios $>500: 1$ ) while the silver is characteristically aggregated nanospherules or branched nanospherule clusters. The cytotoxicity of these materials may be related to their crystallinity since Monarca et al. ${ }^{66}$ demonstrated that fine crystalline silica had a more detrimental effect in lung epithelial cell damage than fine amorphous silica.

Teeguarden et al ${ }^{67}$ have suggested that particokinetics and principles of dosimetry would significantly improve the basis for nanoparticle toxicity assessment and increase the predictive power and scalability of such assays. The authors applied particokinetics in the reinterpretation of published dose-response data. For instance, they extended their analysis by comparing the $\mathrm{EC}_{50}$ on a nominal media particle surface area/milliliter basis as well as adjusting the $\mathrm{EC}_{50}$ for approximate delivery from the results obtained by Hussein et al. ${ }^{64}$ It was observed that $15 \mathrm{~nm}$ silver nanoparticles appear $c a .4000$ times less toxic than micron-sized cadmium oxide particles on a $\mathrm{cm}^{2} \mathrm{~mL}^{-1}$ media basis, but are only $c a$. 50 times less toxic when differences in delivery to adherent cells were considered. The authors concluded that simple surrogates of dose can cause significant misinterpretation of response and uptake data for nanoparticles in vitro.

Silver nanoparticles were detected in the lung, liver, kidney, spleen, brain, heart, and blood of rats after inhalation of ultrafine particles $(4-10 \mathrm{~nm})$. In the liver, kidney, spleen, brain and heart, low concentrations of silver were detected. The level of silver in the liver and in the lungs decreased rapidly with time. In blood, significant amounts of silver were detected on day 0 and thereafter decreased rapidly. Nasal cavities and lung-associated lymph nodes showed relatively high concentrations. ${ }^{68}$ When rats received an aqueous suspension of agglomerated ultrafine silver particles by intratracheal instillation, a portion of the agglomerates remained insoluble in the alveolar macrophages and in the septum for at least 7 days, but a rapid clearance of instilled water-soluble silver nitrate from the lung was observed ${ }^{68} \mathrm{~A}$ possible mechanism for the fast clearance is that whereas agglomerated silver nanoparticles remain insoluble in alveolar macrophages, ultrafine silver nanoparticles were dissolved rapidly in the lung allowing silver to enter the blood capillaries by diffusion. ${ }^{68}$

Toxicity and biocompatibility of silver nanoparticles were evaluated in vivo and in real time using zebrafish embryos. ${ }^{69}$ The embryos were treated with spherical silver nanoparticles with average diameters of $11.6 \pm 3.5 \mathrm{~nm}$ synthesized by reducing $\mathrm{AgClO}_{4}$ with reducing agents (sodium citrate and sodium borohydride) and were monitored until $120 \mathrm{~h}$ post fertilization. The results show that a single silver nanoparticle is transported into and out of embryos through chorion pore canals and the biocompatibility and toxicity of silver nanoparticles and types of abnormalities observed in zebrafish are highly dependent on the dose of silver nanoparticles, with a critical concentration of $0.19 \mathrm{nmol} \mathrm{L}^{-1}$. Following the same methodology results with zebrafish suggested that silver nanoparticles induce a dose-dependent toxicity in embryos, which hinders normal development. ${ }^{70}$

The short-term toxicity of silver nanoparticles and ionic silver $\left(\mathrm{Ag}^{+}\right)$to photosynthesis in Chlamydomonas reinhardtii was examined. Silver nanoparticles ranged in size from 10 to $200 \mathrm{~nm}$ with most particles around $25 \mathrm{~nm}$ and about $1 \%$ of the silver nanoparticles were present as silver ions. Based on total silver concentration, toxicity was 18 times higher for $\mathrm{AgNO}_{3}$ than for silver nanoparticles. It was verified that $1 \%$ of total $\mathrm{Ag}$ in silver nanoparticles was present as $\mathrm{Ag}^{+}$ions. Thus, the toxicity of silver nanoparticles, as a function of the free silver ions concentration, was much higher than that of $\mathrm{AgNO}_{3}$. Furthermore, it was verified that silver nanoparticles toxicity is mediated by silver ions. All the results indicate that the interaction of these particles with algae influences the toxicity of silver nanoparticles through silver ion formation in the algal interface. Therefore, the particles contributed to the toxicity as a source of silver ions which was formed in the presence of algae..$^{71}$

Panyala et al. ${ }^{72}$ have summarized the hazardous effects of silver nanoparticles in the environment and their toxic effects on human health. Biodistribution, organ accumulation, degradation, possible adverse effects and toxicity as well as major questions associated with the increased medical use of nanosilver and related nanomaterials were discussed. ${ }^{73}$

Toxicity of starch-coated silver nanoparticles was studied using normal human lung fibroblast cells (IMR-90) and human glioblastoma cells (U251), through changes in cell morphology, cell viability, metabolic activity, and oxidative stress. A possible mechanism of toxicity was proposed which involved disruption of the mitochondrial respiratory chain by silver nanoparticles leading to production of reactive oxygen species (ROS) and interruption of ATP synthesis, which in turn cause DNA damage. ${ }^{74}$

The immunological response of macrophages to physically produced pure gold and silver nanoparticles (in three different sizes) was investigated in vitro. The treatment of either type of nanoparticles at $\geq 10 \mathrm{ppm}$ dramatically decreases the population and increases the 
size of the macrophages. Both nanoparticles enter the cells but only gold nanoparticles (especially those with smaller diameter) up-regulate the expressions of pro-inflammatory genes interlukin-1 (IL-1), interlukin-6 (IL-6), and tumor necrosis factor (TNF-a). Transmission electron microscopic images show that silver nanoparticles and gold nanoparticles are both trapped in vesicles in the cytoplasma, but only gold nanoparticles were organized into a circular pattern. The authors speculated that part of the negatively charged gold nanoparticles might adsorb serum protein and enter cells via the more complicated endocytotic pathway, which results in higher cytotoxicity and immunological response of gold as compared to silver nanoparticles. ${ }^{75}$

The gene expression in different regions of the mouse brain (adult male C57BL/6N mice) was studied by i.p. administration of $100 \mathrm{mg} \mathrm{kg}^{-1}, 500 \mathrm{mg} \mathrm{kg}^{-1}$ or $1000 \mathrm{mg} \mathrm{kg}^{-1}$ silver nanoparticles $(25 \mathrm{~nm})$. The animals were sacrificed after $24 \mathrm{~h}$. Total RNA was isolated from each of three brain regions (caudate nucleus, frontal cortex, hippocampus) and RT-PCR analysis was performed. Through gene expression the data suggest that silver nanoparticles may produce neurotoxicity by generating free radical-induced oxidative stress and by altering gene expression, producing apoptosis and neurotoxicity. ${ }^{76}$

Inflammatory responses and pulmonary function changes in rats during 90 days of inhalation exposure to silver nanoparticles $(18 \mathrm{~nm})$ was studied. Histopathological examinations indicated dose-dependent increases in lesions related to silver nanoparticle exposure, such as infiltrate mixed cell and chronic alveolar inflammation, including thickened alveolar walls and small granulomatous lesions. Considering all the results together, the decreases in the tidal volume and minute volume and other inflammatory responses after prolonged exposure to silver nanoparticles apparently indicate that nanosized particle inhalation exposure can induce lung function changes. ${ }^{77,78}$

In vitro interactions of 7-20 $\mathrm{nm}$ spherical silver nanoparticles with primary fibroblasts and primary liver cells isolated from Swiss albino mice were studied. Upon exposure to silver nanoparticles for $24 \mathrm{~h}$, morphology of primary fibroblasts and primary liver cells remained unaltered up to $25 \mu \mathrm{g} \mathrm{mL}^{-1}$ and $100 \mu \mathrm{g} \mathrm{mL}^{-1}$ silver nanoparticles, respectively. Metabolic studies, apoptotic processes and morphological transformations clearly suggest that although silver nanoparticles seem to enter the eukaryotic cells, cellular antioxidant mechanisms protect the cells from possible oxidative damage. Besides that, they exhibited these properties, in conjunction with the finding that primary cells possess much higher silver nanoparticle tolerances than the concentration in the gel $\left(c a .20 \mu \mathrm{g} \mathrm{g}^{-1}\right)$ that is used in the form of a topical antimicrobial gel formulation for the treatment of burns and wounds, which suggesting a reasonable safety for the formulation and warrants further study for possible human application. ${ }^{79}$

Toxicity evaluations of silver nanoparticles of different sizes using mitochondrial and cell membrane viability along with reactive oxygen species (ROS) were studied. After $24 \mathrm{~h}$ of exposure, viability measurments significantly decreased with increasing dose (10-75 $\left.\mu \mathrm{g} \mathrm{mL}^{-1}\right)$ of silver nanoparticles $(15 \mathrm{~nm}$ and $30 \mathrm{~nm})$. A more than 10 -fold increase of ROS levels in cells exposed to $50 \mu \mathrm{g} \mathrm{mL}^{-1}$ silver nanoparticles $(15 \mathrm{~nm})$ suggested that the cytotoxicity of silver nanoparticles is probably mediated through oxidative stress. Traditional inflammatory mediators, such as levels of cytokines/chemokines, including tumor necrosis factor, macrophage inhibitory protein and interleukin-6, were released into the culture media and examined. After $24 \mathrm{~h}$ of exposure to silver nanoparticles $(15 \mathrm{~nm})$, a significant inflammatory response but no detectable level of interleukin-6 was observed. A size-dependent toxicity for silver nanoparticles was observed, and it was suggested that one predominant mechanism of toxicity could be through oxidative stress. ${ }^{80}$

Cytotoxicity of several coated silver nanoparticles was established using the Trypan Blue exclusion assay, and then they were mixed with respiratory syncytial virus (RSV) and added to HEp- 2 cells. The effectiveness of RSV inhibition was then evaluated by microscopic examination for syncytia formation and by immunofluorescence microscopy. The results revealed that poly(N-vinyl-2-pyrrolidone)-coated silver nanoparticles, which showed low toxicity to cells at low concentrations, inhibited RSV infection by $44 \%$, a significant reduction compared to controls, thus appearing to be a promising candidate for future RSV treatment research in animal models. ${ }^{81}$

Very recently, ecosystem protection by a biotechnological process of an effluent containing silver nanoparticles was published. ${ }^{82}$ In this study, the bacteria Chromobacterium violaceum was used as biological filter to capture silver nanoparticles released after several washings from cotton fabrics impregnated with biological silver nanoparticles. After silver nanoparticles capture, the bacteria morphology was changed, but the bacteria was still alive. However, the morphology was completely restored after a new culture. This bacterium efficiently absorbed the particles from the wash water, demonstrating an excellent method to remove metallic nanoparticles from effluents, avoiding any effect to the eco-environment. ${ }^{82}$ 


\section{Conclusions}

Nanotechnology represents a modern and innovative approach to develop and test new formulations based on metallic nanoparticles with antimicrobial properties. Silver nanoparticles represent a prominent nanoproduct with potential application in medicine and hygiene. Characteristics of silver nanoparticles such as shape and size are important not only for augmenting the antimicrobial activity, but also for reducing tissue and eukaryotic cell toxicities. The possible risks to human health posed by silver nanoparticles and the increased entry into the environment, with subsequent spread of microbial resistance, are of increasing concern given the rise of silver-containing products on the market. Therefore, further studies are needed to fully characterize the toxicity and the mechanisms involved with the antimicrobial activity of these particles. Finally, this is an important area of research that deserves all our attention owing to its potential application in the fight against multi-drug resistant microorganisms.

\section{Acknowledgments}

Support from FAPESP, CAPES and the Brazilian Network of Nanocosmetics (CNPq/MCT) are acknowledged.

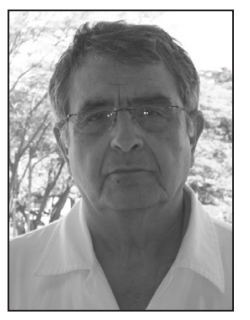

Nelson Durán is a Professor of Chemistry at the Universidade Estadual de Campinas - UNICAMP (Brazil). He received his PhD at University of Porto Rico (USA) working on photolysis and thermolysis of 1,2-dioxolanes (1972). Associated Professor at the Universidad Catolica de Valparaiso, Chile (1973-1975) and carried out Visiting Professorship at Universidade de São Paulo, Brazil (1975), investigating enzymatic generation of excited states intermediates. In 1978, he jointed the Chemistry Institute of UNICAMP (Brazil) working in Biological Chemistry and Biotechnology. His present research interests are nanobiotechnology in cosmetics and in pharmaceuticals, besides metallic nanoparticles as antibiotics carriers. He is the Coordinator of the Brazilian Nanobiotechnology Network; Member of the Brazilian Nanocosmetics and Carbon Nanotubes Networks and of the Committee of Brazil-Argentina Nanotechnology Center and belongs to the Consultant Committee for the Nanotechnology area in the Brazilian Science and Technology Ministry.

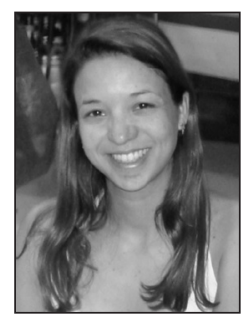

Priscyla D. Marcato received her $P h D$ in Sciences from Universidade Estadual de Campinas - UNICAMP (Brazil) (2009) in Professor N. Durán's group, working with nanostructured pharmaceuticals and cosmetics carriers. Her work is focused on the production, characterization and application of biodegradable polymers, solid lipid nanoparticles and biogenic silver nanoparticles.

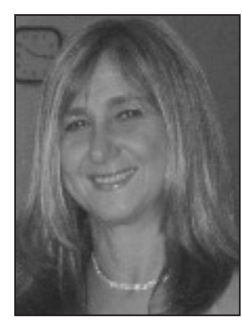

Roseli De Conti received her PhD in Organic Chemistry from Universidade Estadual de Campinas - UNICAMP (Brazil) and her MSc in Technological Chemistry area from The University of Manchester-Institute of Science and Technology (UMIST). She graduated in Chemistry from UNICAMP. Nowadays she is Professor at Universidade do Espírito Santo do PinhalUNIPINHAL and Associated Researcher at UNICAMP. Her research is focused on nanobiotechnology, organic synthesis and biocatalysis.

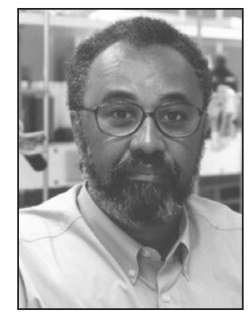

Oswaldo L. Alves is a full professor in the Department of Inorganic Chemistry of the Institute of Chemistry at UNICAMP (Brazil) and founder/ scientific co-ordinator of the Solid State Chemistry Laboratory (LQES). He received his $P h D$ in sciences (1977) from UNICAMP working with vibrational spectroscopy of molecular complexes and studied Raman spectroscopy of materials as part of a postdoctoral stage at LASIR-CNRS, France (1979-1981). Alves' research interests include layered compounds, intercalation chemistry, integrated chemical systems, nanocomposites, quantum-dots and the interaction of nanostructures with biological systems. He has authored or co-authored of more than 150 publications including research articles and reviews, he holds eighteen patents. He has been the president of the Brazilian Chemical Society (1998-2000) and is a member of the Brazilian Academy of Sciences.

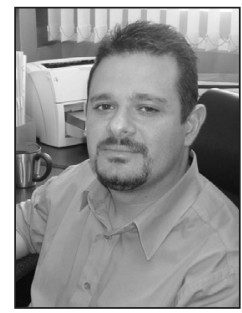

Fabio T. M. Costa has obtained his PhD degree from Universidade Federal de São Paulo (Brazil) (2001) and assumed a post-doctoral position at Unité de Parasitologie ExpérimentaleUniversité de La Méditerrané / Institut Pasteur in Marseilles, France (2001- 
2003). He is an Assistant Professor in the Department of Genetics, Evolution and Bioagents at Institute of Biology of Universidade Estadual de Campinas - UNICAMP (Brazil). His research is focused on drug and vaccine development against malaria.

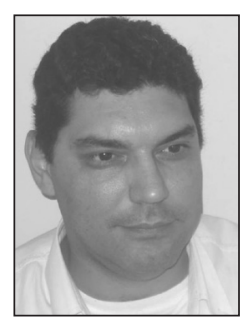

Marcelo Brocchi received his PhD in Genetics of Microorganisms from Universidade Estadual de Campinas - UNICAMP (Brazil) (1997). He is an Associated Professor of Microbiology in the Department of Genetics, Evolution and Bioagents at Institute of Biology of UNICAMP. His research is focused on pathogenesis, diversity and genomic studies of bacteria and bacteriophages.

\section{References}

1. Tenover, F. C.; Am. J. Infect. Control. 2006, 34, S3.

2. Melaiye, A.; Youngs, W. J.; Expert Opin. Ther. Pat. 2005, 15, 125.

3. Marcato, P. D.; Durán, N.; J. Nanosci. Nanotechnol. 2008, 8, 2216.

4. Matsumura, Y.; Yoshikata, K.; Kunisaki, S. I.; Tsuchido, T.; Appl. Environ. Microbiol. 2003, 69, 4278.

5. Alt, V.; Bechert, T.; Steinrucke, P.; Wagener, M.; Seidel, P.; Dingeldein, E.; Domann, E.; Schnettler, R.; Biomaterials 2004, 25, 4383.

6. Baker, C.; Pradhan, A.; Pakstis, L.; Pochan, D. J.; Shah, S. I.; J. Nanosci. Nanotechnol. 2005, 5, 244.

7. Morones, J. R.; Elechiguerra, J. L.; Camacho, A.; Holt, K.; Kouri, J. B.; Ramirez, J. T.; Yacaman, M. J.; Nanotechnology 2005, 16, 2346.

8. White, R. J.; Br. J. Nurs. 2001, 10, S3.

9. Kim, J. S.; Kuk, E.; Yu, K. N.; Kim, J. H.; Park, S. J.; Lee, H. J.; Kim, S. H.; Park, Y. K.; Park, Y. H.; Hwang, C. Y.; Kim, Y. K.; Lee, Y. S.; Jeong, D. H.; Cho, M. H.; Nanomedicine 2007, 3, 95 .

10. Durán, N.; Marcato, P. D.; Alves, O. L.; De Souza, G. I. H.; Esposito, E.; J. Nanobiotechnol. 2005, 3, 1.

11. Durán, N.; Marcato, P. D.; Alves, O. L.; De Souza, G. I. H.; Espósito, E.; J. Biomed. Nanotechnol. 2007, 3, 203.

12. Kalishwaralal, K.; Deepak, V.; Ramkumarpandian, S.; Nellaiah, H.; Sangiliyand, G.; Mater. Lett. 2008, 62, 4411.

13. Mohanpuria, P.; Rana, N. K.; Yadav, S. K.; J. Nanopart. Res. 2008, 10, 507.

14. Mukherjee, P.; Roy, M.; Mandal, B. P.; Dey, G. K.; Mukherjee, P. K.; Ghatak, J.; Tyagi, A. K.; Kale, S. P.; Nanotechnology 2008, 19, 075103.
15. Sadowski, Z.; Maliszewska, I. H.; Grochowalska, B.; Polowczyk, I.; Koźlecki, T.; Mater. Sci., Poland 2008, 26, 419.

16. Maliszewska, I.; Sadowski, Z.; J. Phys. Conf. Ser. 2009, 146, 012024.

17. Ingle, A.; Gade, A.; Pierrat, S.; Sönnichsen, C.; Rai, M.; Curr. Nanosci. 2008, 4, 141.

18. Shankar, S. S.; Rai, A.; Ahmad, A.; Sastry, M.; J. Colloid Interface Sci. 2004, 275, 496.

19. Song, J. Y.; Kim, B. S.; Bioprocess Biosyst. Eng. 2009, $32,79$.

20. Liau, S. Y.; Read, D. C.; Pugh, W. J.; Furr, J. R.; Russell, A. D.; Lett. Appl. Microbiol. 1997, 25, 279.

21. Feng, Q. L.; Wu, J.; Chen, G. O.; Cui, F. Z.; Kim, T. N.; Kim, J. O.; J. Biomed. Mater. Res., Part A 2000, 52, 662.

22. Jung, W. K.; Koo, H. C.; Kim, K. W.; Shin, S.; Kim, S. H.; Park, Y. H.; Appl. Environ. Microbiol. 2008, 74, 2171.

23. Sondi, I.; Salopek-Sondi, B.; J. Colloid Interface Sci. 2004, $275,177$.

24. Gogoi, S. K.; Gopinath, P.; Paul, A.; Armes, A.; Ghosh, S. S.; Chattopadhyay, A.; Langmuir 2006, 22, 9322.

25. Mohan, Y. M.; Lee, K.; Premkumar, T.; Geckeler, K. E.; Polymer 2007, 48, 158.

26. Hussain, S.; Javorina, A.; Schrand, A.; Duhart, H. Ali, S.; Schlager, J.; Toxicol. Sci. 2006, 92, 456.

27. Lok, C. N.; Ho, C. M.; Chen, R.; He, Q. Y.; Yu, W. Y.; Sun, H.; Tam, P. K.; Chiu, J. F.; Che, C. M.; JBIC, J. Biol. Inorg. Chem. 2007, 12, 527.

28. Raffin, M.; Hussain, F.; Bhatti, T. M.; Akhter, J. I.; Hameed, A.; Hasan, M. M.; J. Mater. Sci. Technol. 2008, 24, 192.

29. Gade, A. K.; Bonde, P.; Ingle, A. P.; Marcato, P. D.; Durán, N.; Rai, M. K.; J. Biobased Mater. Bioenergy 2008, 2, 243.

30. Lok, C. N.; Ho, C. M.; Chen, R.; He, Q. Y.; Yu, W. Y.; Sun, H.; Tam, P. K.; Chiu, J. F.; Che, C. M.; J. Proteome Res. 2006, 5, 916.

31. Chopra, I.; J. Antimicrob. Chemother. 2008, 59, 587.

32. Silver, S.; FEMS Microbiol. Rev. 2003, 27, 341.

33. Silver, S.; Phung, L. T.; Silver, G.; J. Ind. Microbiol. Biotechnol. 2006, 33, 627.

34. Nanda, A.; Saravanan, M.; Nanomedicine: NBM 2009, doi:10.1016/j.nano.2009.01.012

35. Pal, S.; Tak, Y. K.; Song, J. M.; Appl. Environ. Microbiol. 2007, 73, 1712.

36. Sharma, V. K.; Yngard, R. A.; Lin, Y.; Adv. Colloid Interface Sci. 2009, 145, 83.

37. Panacek, A.; Kvitek, L.; Prucek, R.; Kolar, M.; Vecerova, R.; Pizurova, N.; Sharma, V. K.; Nevecna, T.; Zboril, R.; J. Phys. Chem. B 2006, 110, 16248.

38. Choi, O.; Hu, Z.; Environ. Sci. Technol. 2008, 42, 4583.

39. Liong, M.; France, B.; Bradley, K. A.; Zink, J. I.; Adv. Mater. 2009, 21, 1684.

40. Li, P.; Li, J.; Wu, C.; Wu, Q.; Li, J.; Nanotechnology 2005, 16, 1912. 
41. Vigneshwaran, N.; Kathe, A. A.; Varadarajan, P. V.; Nachane, R. P.; Balasubramanya, R. H.; Langmuir 2007, 23, 7113.

42. Basavaraja, S.; Balaji, S. D.; Lagashetty, A.; Rajasab, A. H.; Venkataraman, A.; Mater. Res. Bull. 2008, 43, 1164.

43. Parikh, R. Y.; Singh, S.; Prasad, B. L. V.; Patole, M. S.; Sastry, M.; Shouche, Y. S.; ChemBioChem 2008, 9, 1415.

44. Balaji, S. D.; Basavaraja, S.; Deshpande, D. J.; Mahesh, B.; Prabhakara, B. K.; Venkataraman, A.; Colloids Surf., B 2009, $68,88$.

45. Durán, N.; Marcato, P. D.; De Conti, R.; Alves, O. L.; Brocchi, M.; Nanotoxicology 2008, 2, S32.

46. Marcato, P. D.; De Conti, R.; Betrgmann, B. R.; Durán, N.; Proceeding of the $7^{\text {th }}$ Brazilian MRS Meeting (SBPMAT), Guarujá, Brazil, 2008.

47. Shahverdi, A. R.; Fakhimi, A.; Shahverdi, H. R.; Minaian, S.; Nanomedicine 2007, 3, 168.

48. De Sousa, A.; Mehta, D.; Leavitt, R. W.; Curr. Sci. 2006, 91, 926.

49. Birla, S. S.; Tiwari, V. V.; Gade, A. K.; Ingle, A. P.; Yadav, A. P.; Rai, M. K.; Lett. Appl. Microbiol. 2009, 48, 173.

50. Wei, Q. S.; Ji, J.; Fu, J. H.; Shen, J. C.; Sci. China, Ser. B: Chem. 2007, 50, 418.

51. Patil, S. S.; Dhumal, R. S.; Varghese, M. V.; Paradkar, A. R.; Khanna, P. K.; Synth. React. Inorg., Met.-Org., Nano-Met. Chem. 2009, 39, 65.

52. El-Ansary, A.; Al-Daihan, S.; J. Toxicol. 2009, 2009, 754810.

53. Hussain, S. M.; Schlager, J. J.; Toxicol. Sci. 2009, 108, 223.

54. Braydich-Stolle, L.; Hussain, S.; Schlager, J.; Hofmann, M. C.; Toxicol. Sci. 2005, 88, 412.

55. Oberdorster, G.; Int. Arch. Occup. Environ. Health 2001, 74, 1.

56. Jani, P.; Halbert, G. W.; Langridge, J.; Florence, A. T.; J. Pharm. Pharmacol. 1990, 42, 821.

57. Kreilgaard, M.; Adv. Drug Delivery Rev. 2002, 54, S77.

58. Oberdorster, G.; Sharp, Z.; Atudorei, V.; Elder, A.; Gelein, R.; Lunts, A.; Kreyling, W.; Cox, C.; J. Toxicol. Environ. Health, Part A 2002, 65, 1531.

59. Oberdorster, G.; Sharp, Z.; Atudorei, V.; Elder, A.; Gelein, R.; Kreyling, W.; Cox, C.; Inhalation Toxicol. 2004, 16, 437.

60. Chen, Y.; Xue, Z.; Zheng, D.; Xia, K.; Zhao, Y.; Liu, T.; Long, Z.; Xia, J.; Curr. Gene Ther. 2003, 3, 273.

61. Borm, P. J.; Kreyling, W.; J. Nanosci. Nanotechnol. 2004, 4, 521.

62. Burd, A.; Kwok, C.H.; Hung, S.C.; Chan, H.S.; Gu, H.; Lam, W.K.; Li, H.; Wound Repair Reg. 2007, 15, 94.

63. Totaro, P.; Rambaldini, M.; Interact. CardioVascular Thoracic Sur. 2009, 8, 153.

64. Hussain, S.; Hess, K.; Gearhart, J.; Geiss, K.; Schlager, J.; Toxicol. In vitro 2005, 19, 975.

65. Soto, K. F.; Carrasco, A.; Powell, T. G.; Garza, K. M.; Murr, L. E.; J. Nanoparticle Res. 2005, 7, 145.
66. Monarca, S.; Crebelli, R.; Feretti, D.; Zanardini, A.; Fuselli, S.; Fillini, L.; Resola, S.; Bonardelli, P.G.; Nardi, G.; Sci. Total Environ. 1997, 205, 137.

67. Teeguarden, J. G.; Hinderliter, P. M.; Orr, G.; Thrall, B. D.; Pounds, J. G.; Toxicol. Sci. 2007, 95, 300.

68. Takenaka, S.; Karg, E.; Roth, C.; Schulz, H.; Ziesenis, A.; Heinzmann, U.; Schramel, P.; Heyder, J.; Environ. Health Perspect. 2001, 109, 547.

69. Lee, K. J.; Nallathamby, P. D.; Browning, L. M.; Osgood, C. J.; Xu, X-H. N.; ACS Nano 2007, 1,133.

70. AshaRani, P. V.; Wu, Y. L.; Gong, Z.; Valiyaveettil, S.; Nanotechnology 2008, 19, 255102.

71. Navarro, E.; Piccapietra, F.; Wagner, B.; Marconi, F.; Kaegi, R.; Odzak, N.; Sigg, L.; Behra, R.; Environ. Sci. Technol. 2008, 42, 8959

72. Panyala, N. R.; Peña-Méndez, E. M.; Havel, J.; J. Appl. Biomed. 2008, 6, 47.

73. Chen, X.; Schluesener, H. J.; Toxicol. Lett. 2008, 176, 1.

74. AshaRani, P. V.; Mun, G. L. K.; Hande, M. P.; Valiyaveettil, S.; ACS Nano 2009, 3, 279.

75. Yen, H. J.; Hsu, S. H.; Tsai, C. L.; Small 2009, 5, 1553.

76. Rahman, M. F.; Wang, J.; Patterson, T. A.; Saini, U. T.; Robinson, B. L.; Newport, G. D.; Murdock, R. C.; Schlager, J. J.; Hussain, D. M.; Ali, S. F.; Toxicol. Lett. 2009, 187, 15.

77. Sung, J. H.; Ji, J. H.; Yoon, J. U.; Kim, D. S.; Song, M. Y.; Jeong, J.; Han, B. S.; Han, J. H.; Chung, Y. H.; Kim, J.; Kim, T. S.; Chang, H. K.; Lee, E. J.; Lee, J. H.; Yu, I. J.; Inhalation Toxicol. 2008, 20, 567.

78. Sung, J. H.; Ji, J. H.; Park, J. D.; Yoon, J. U.; Kim, D. S.; Jeon, K. S.; Song, M. Y.; Jeong, J., Han, B. S.; Han, J. H.; Chung, Y. H.; Chang, H. K.; Lee, J. H.; Cho, M. H.; Kelman, B. J.; Yu, I. J.; Toxicol. Sci. 2009, 108, 452.

79. Arora, S.; Jain, J.; Rajwade, J. M.; Paknikar, K. M.; Toxicol. Appl. Pharmacol. 2009, 236, 310.

80. Carlson, C.; Hussain, S. M.; Schrand, A. M.; Braydich-Stolle, L. K.; Hess, K. L.; Jones, R. L.; Schlager, J. J.; J. Phys. Chem. B 2008, 112, 13608.

81. Sun, L.; Singh, A. K.; Vig, K.; Pillai, S. R.; Singh, S. R.; J. Biomed. Nanotechnol. 2008, 4, 149.

82. Durán, N.; Marcato, P. D.; Alves, O.L.; Da Silva, J. P. S., De Souza, G. H. I.; Rodrigues, F. A.; Esposito, E.; J. Nanoparticles Res. 2009, 12, 285.

Received: September 9, 2009 Web Release Date: April 22, 2010

FAPESP helped in meeting the publication costs of this article. 